II Meer B Baker JA The Stockton geriatric rating scale f Gerontol 1966:21:392 403.

12 Mac Nair DM, Kahn RJ. Self assessment of cognitive deficits. In: Crook T, Ferris S, Bartus R, eds. Assessment in geriatric psychopharmacology. New Canaan, Conn: Marc Powley, 1983:137-44.

13 Marx JL. Alzheimer's drug trial put on hold. Science 1987;238:1041-2.

4 Hills M, Armitage P. The two-period cross-over clinical trial. Br 7 Clin Pharmacol 1979;8:7-20.

5 SAS Institute. SAS user's guide: statistics, version 5. Cary, NC: SAS Institute, 1985.

16 Kaye WH, Sitaram N, Weingartner H. Modest facilitation of memory in dementia with combined lecithin and anticholinesterase treatment. Biol Psychiatry 1982:17:275-80.

17 Gauthier $S$ Masson $H$, Gauthier $L$ et al Tetrahydroaminoacridine and lecithin in Alzheimer's disease. In: Giacobini E, Becker R, eds. Current lecithin in Alzheimer's disease. In: Glacobini E, Becker R, eds. Cum

18 Little A, Levy R, Chuaqui-Kidd P, Hand D. A double-blind placebo- controlled trial of high-dose lecithin in Alzheimer's disease. I Neurol Neurosurg Psychiatry 1985; 48:736-42.

19 Perry EK, Tomlinson BE, Blessed G, et al. Correlation of cholinergic abnormalities with senile plaques and mental scores in senile dementia. Br Med f 1978;ii:1457-9.

20 Pocock SJ, Hughes MD, Lee RJ. Statistical problems in the reporting of clinical trials. A survey of three medical journals. N Engl f Med 1987;317: 426-32.

21 Penn RD, Martin EM, Wilson RS, Fox JH, Savoy SM. Intraventricular bethanechol infusion for Alzheimer's disease: results of a double-blind and escalating-dose trial. Neurology 1988:38:219-22.

22 Ames DJ, Bhatal PS, Davies BM, Fraser JRE. Hepatotoxicity of tetrahydroacridine, Lancet 1988; : 887 .

23 Wilcock GK, Surmon D, Forsyth D, Morgan R. Cholinergic side-effects of tetrahydroaminoacridine. Lancet 1988;ii:1305.

Accepted 13 December 1989)

\title{
Risk of malaria in British residents returning from malarious areas
}

\author{
P A Phillips-Howard, A Radalowicz, J Mitchell, D J Bradley
}

\section{Abstract}

Objectives-To identify which British residents travelling abroad are at greatest risk of malaria infection, and to determine the efficacy of malaria chemoprophylaxis for preventing $\boldsymbol{P}$ falciparum infections in tropical Africa.

Design-Prospective cohort study (case-base linkage) with routine national surveillance systems. Denominators (base population) were obtained from monitoring a random sample of returning British travellers with the international passenger survey. Numerators (cases) were obtained from reports of malaria infections in British residents, through the Malaria Reference Laboratory network.

Setting-International passenger survey conducted at passport control of international airports in Britain. Malaria reports received nationally were collated centrally in London.

Subjects -2948 British residents $(0 \cdot 2 \%)$ returning to Britain in 1987 randomly selected and questioned and 1052 British residents with microscopically confirmed malaria infections in 1987 , whose case reports were reviewed and on whom additional data were collected by postal survey.

Main outcome measures-Annual incidence subdivided by categories of risk. Chemoprophylactic efficacy for east and west Africa by principal regimens and compliance.

Results-Annual rates of reported infection per 100000 travellers to Oceania were 4100; to west and east Africa were 375 and 172 respectively; to Latin America, the Far East, and the Middle East were 12, 2 , and 1 respectively. Immigrants visiting friends and relatives in Ghana and Nigeria were at greatest risk (1303 and 952 per 100000 respectively) in west Africa. Business travellers to Kenya experienced the highest attack rates in east Africa (465 per 100000 ). Age-sex specific attack rates varied by region. No prophylaxis was reported to have been used by $23 \%$ of British visitors to west Africa, $17 \%$ to east Africa, $46 \%$ to central or southern Africa, and $58 \%$ visiting south Asia. The efficacy of chloroquine plus proguanil against $\boldsymbol{P}$ falciparum infection was $73 \%$ and $54 \%$ in west and east Africa respectively. Lower values were obtained for chloroquine alone and proguanil alone. The efficacy of Maloprim (pyrimethamine-dapsone) was $61 \%$ in west Africa, but only $9 \%$ in east Africa. Visitors to west Africa who did not comply with their chemoprophylactic regimen were at a $\mathbf{2} \cdot \mathbf{5}$-fold higher risk of infection than fully compliant users. Non-compliant visitors to east Africa had similar rates of infection as nondrug users.
Conclusions - In 1987 chloroquine plus proguanil was the preferred chemoprophylactic regimen for $P$ falciparum infection in Africa; antimalarial drugs must be taken regularly to be effective.

\section{Introduction}

The control of malaria in semi-immune indigenous communities has become increasingly difficult with the spread of chloroquine resistant strains of Plasmodium falciparum. ' There are also serious public health implications for international travellers, most of whom have no protective immunity against malaria. The reported incidence of $P$ falciparum infections in Britain has risen sharply in recent years with over 1000 cases recorded by the Malaria Reference Laboratory in $1988 .^{2}$ The trend can be expected to continue as more travellers visit areas where the degree and intensity of transmission of resistant strains of $P$ falciparum will also increase. Protection against infection in areas with a high transmission of $P$ falciparum parasites has become a particular problem. Though some drugs-namely, pyrimethamine-dapsone (Maloprim), pyrimethaminesulphadoxine (Fansidar), and amodiaquine-have offered greater protection against infection than chloroquine or proguanil, the risk of serious adverse reactions associated with their use has been considered to be unacceptable in otherwise healthy subjects, unless the risk of a potentially fatal infection is high. ${ }^{3+}$ Chloroquine plus proguanil has thus been the principal regimen advised for British travellers visiting areas of sub-Saharan Africa, the origin of over $80 \%$ of $P$ falciparum infections imported into Britain. ${ }^{5}$ It is not known, however, how much protection this regimen now offers non-immune visitors exposed to $P$ falciparum infections. Early formulation of this regimen originated from one retrospective cohort study conducted between 1978 and 1983, which illustrated empirically that $200 \mathrm{mg}$ of proguanil daily, alone and combined with chloroquine, was a highly effective regimen in east Africa. ${ }^{6}$ Although more recent prospective cohort studies have been performed, efficacy data generated from these studies have not been adequate to guide current recommendations. ${ }^{7-9}$ The limitations of such cohort studies are now well recognised; they can be expected to provide data on efficacy only for select populations at very high risk of malaria (above $1 \%$ ), if drug prophylaxis is controlled, and when the diagnoses are verified microscopically. ${ }^{10}$ Data on the risk of infection with malaria in different subgroups and the relative efficacy of chemoprophylactic regimens under varying epidemiological conditions are, however, required to ensure that recommendations for chemo-
1211 Geneva 27

Switzerland.

Br.Med f 1990;300:499-503 
prophylactic drugs are targeted appropriately. Alternative methods of obtaining such data must thus be sought and we describe one method, case-base linkage, here. We used data generated from national surveillance systems to measure the rates of infection in returning British residents in 1987, the efficacy of commonly prescribed chemoprophylactic regimens for travellers visiting east and west Africa, and the influence of poor compliance on the protective value of these regimens.

\section{Subjects and methods}

CASE ÅND BASE POPULATION

Malaria cases-All of the 1816 microscopically confirmed cases of malaria in Britain reported to the Malaria Reference Laboratory during 1987 were investigated. Of these, 1052 patients were British residents, broadly defined as any person resident in the United Kingdom prior to travel. These patients were followed up individually to verify reported surveillance data and to collect additional data missing from the routine report forms. ${ }^{11}$

Data on travel in the base population were derived from a continuous monitoring system, the international passenger survey, designed and implemented by the Office of Population Censuses and Surveys, and from the Department of Employment. The survey methods have been reported in full elsewhere. ${ }^{12}$ Briefly, a $0 \cdot 2 \%$ stratified sample of returning British travellers was questioned on entering Britain by trained interviewers with a standard questionnaire. Throughout the study year, in addition to routine questions, 2948 sampled British residents visiting malarious areas were questioned on their use of, and compliance with, recommended chemoprophylactic drug regimens. The total number of returning British residents visiting malarious areas was calculated to be 1.6 million. This was estimated by assigning weights to each sampled traveller, allotted by the Office of Population Censuses and Surveys according to the sampling interval and shift rota operating at the time of incoming flights. Analyses were conducted using the statistical package for the social sciences (SPSS X).

\section{CASE-BASE LINKAGE}

Analyses of rates of infection-Measurements of rates of infection and the efficacy of drugs were achieved by linking together information on cases in reports of the Malaria Reference Laboratory with that on the base population (from international passenger survey travel statistics) as if both were derived from one single study population. The travel category of patients was adjusted to concur with international passenger survey definitions; tourists were grouped under holiday travellers; business, crew, military, and expatriate patients were redefined as business travellers; and those remaining cases travelling for family reasons (including overseas students receiving education in Britain) were reclassified as visiting friends or relatives. Case and base data were then aggregated to compute species-specific malaria attack rates per 100000 visits to each region and the principal countries of visit. Regional malaria attack rates were calculated according to the purpose of visit of British travellers, their age and sex, and their duration of stay abroad. Two tailed standard normal deviates were used to test significance.

Measurement of chemoprophylactic efficacy-Information on the use of chemoprophylaxis by British patients with malaria was derived first from case report forms and then verified by following up individual patients. Information obtained from the sampled travellers collected during the international passenger survey study was used to estimate the proportion of all travellers using each chemoprophylactic regimen.
These were stratified according to the region of visit and category of traveller. No data on blood drug concentrations were available to verify the reported use of chemoprophylaxis. Malaria attack rates, relative risks, and chemoprophylactic efficacy were calculated to measure the protective effect of commonly prescribed chemoprophylactic drugs against $P$ falciparum infections in British travellers visiting east and west Africa in 1987. Malaria attack rates indicated the incidence of infection per 100000 travellers for each chemoprophylactic regimen. Relative risk was calculated to describe the risk of infection in travellers taking no drugs compared with that in travellers taking chemoprophylaxis. Chemoprophylactic efficacy was estimated using the conventional formula; $\mathrm{CPE}_{\mathrm{i}}=$ $\left(\mathrm{R}^{\circ} \mathrm{CP}-\mathrm{RCP}_{\mathrm{i}}\right) / \mathrm{R}^{\circ} \mathrm{CP} \times 100$ (where $\mathrm{CPE}_{\mathrm{i}}$ equals the percentage reduction in risk attributed to chemoprophylaxis with $\mathrm{CP}_{\mathrm{i}}$ compared with similarly exposed travellers taking no chemoprophylaxis ("CP); $\mathrm{R}^{\circ} \mathrm{CP}$ is the risk of infection in travellers to a specified region without chemoprophylaxis; and $\mathrm{RCP}_{\mathrm{i}}$ is the risk of infection in travellers using $\mathrm{CP}_{\mathrm{i}}$ ). Calculation of $95 \%$ confidence intervals of the relative risk was by Mietinens test-based approximation, using the square root of the $\chi^{2}$ significance value ${ }^{13} ; 95 \%$ confidence interval $=$ relative $\operatorname{risk}^{( \pm 1.96 / x)}$ and $95 \%$ confidence intervals for efficacy were derived from the upper and lower $95 \%$ confidence interval units of the relative risk; relative risk -1/relative risk. Efficacy values and relative risks were then calculated according to the reported compliance, with full compliance defined as the uninterrupted use of chemoprophylactic drugs taken, as prescribed, on the allocated day.

\section{Results}

MALARIA ATTACK RATES

Reported species-specific attack rates by region of infection-British residents visiting Oceania were at the highest risk of malaria infections; $4 \%$ of them were infected on their return to Britain (table I), mainly with $P$ vivax infection acquired during expeditions in Papua New Guinea. Of those visiting sub-Saharan Africa, travellers to west Africa were at greatest risk of $P$

TABLE I-Regional malaria attack rates (per 100000) by species of parasite in returning British residents, 1987

\begin{tabular}{|c|c|c|c|c|}
\hline \multirow{2}{*}{$\begin{array}{l}\text { Region and } \\
\text { principal } \\
\text { countries }\end{array}$} & \multirow{2}{*}{$\begin{array}{l}\text { No of } \\
\text { travellers } \\
(000 \mathrm{~s})^{\star}\end{array}$} & \multicolumn{3}{|c|}{ Reported cases (attack rates) } \\
\hline & & All species & $P$ falciparum & Pvivax \\
\hline \multicolumn{5}{|c|}{ West Africa } \\
\hline Total & $75 \cdot 7$ & $287(379)$ & $246(325)$ & $12(16)$ \\
\hline Nigeria & $26 \cdot 5$ & $147(555)$ & $128(483)$ & $5(19)$ \\
\hline Ghana & $9 \cdot 5$ & $74(779)$ & $66(695)$ & $2(21)$ \\
\hline Gambia & $25 \cdot 4$ & $7(28)$ & $5(20)$ & $1(4)$ \\
\hline \multicolumn{5}{|c|}{ East Africa } \\
\hline Kenya & $49 \cdot 0$ & $73(149)$ & $54(110)$ & $13(27)$ \\
\hline Tanzania & $6 \cdot 6$ & $14(212)$ & $10(151)$ & $4(61)$ \\
\hline \multicolumn{5}{|c|}{ Central or southern Africa } \\
\hline Total & $40 \cdot 6$ & $52(128)$ & $42(103)$ & $6(15)$ \\
\hline Zambia & $14 \cdot 5$ & $20(138)$ & $16(110)$ & $2(14)$ \\
\hline Malawi & 1.9 & $15(789)$ & $14(737)$ & $1(53)$ \\
\hline \\
\hline India & $156 \cdot 4$ & $354(226)$ & $10(6)$ & $339(217)$ \\
\hline Pakistan & $98 \cdot 6$ & $164(166)$ & $5(5)$ & $155(157)$ \\
\hline \multicolumn{5}{|c|}{ Oceania } \\
\hline \multicolumn{5}{|c|}{ Far East or South East Asia } \\
\hline Total & $306 \cdot 4$ & $7(2)$ & $2(<1)$ & $5(2)$ \\
\hline \multirow{6}{*}{ Thailand } & $45 \cdot 7$ & $3(7)$ & $2(4)$ & $1(2)$ \\
\hline & & Latin Ame & & \\
\hline & $57 \cdot 1$ & $7(12)$ & $1(2)$ & $6(11)$ \\
\hline & $201 \cdot 0$ & $\begin{array}{l}\text { Middle East } \\
3(1)\end{array}$ & $1(<1)$ & $2(1)$ \\
\hline & & Other & & \\
\hline & $565 \cdot 7$ & 21 & 10 & 9 \\
\hline Total & $1608 \cdot 0$ & $1052(65)$ & $396(25)$ & $601(37)$ \\
\hline
\end{tabular}

${ }^{\star}$ Estimated from international passenger survey sample survey. 
TABLE II - Malaria attack rates (per 100000 ) by purpose of travel in British travellers, 1987

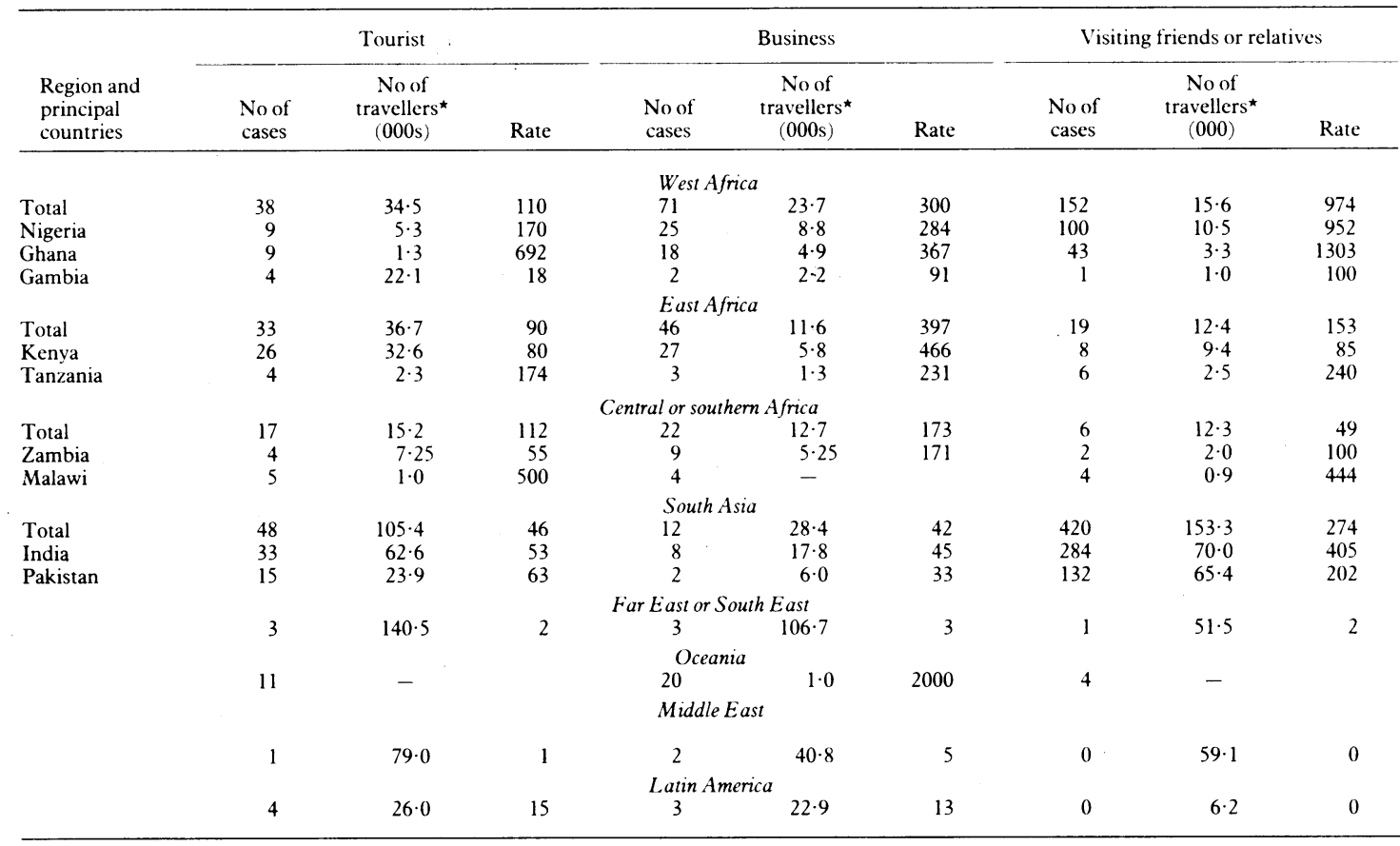

^Estimated from international passenger survey. $\quad-=$ not included in international passenger survey.

TABLE III - Malaria attack rates (per 100000) in British travellers by age and sex, 1987

\begin{tabular}{|c|c|c|c|c|c|c|c|c|c|c|c|c|c|c|c|c|}
\hline \multirow[b]{2}{*}{ Age (years) } & \multicolumn{4}{|c|}{ West Africa } & \multicolumn{4}{|c|}{ East Africa } & \multicolumn{4}{|c|}{ Central or Southern Africa } & \multicolumn{4}{|c|}{ South Asia } \\
\hline & Male & Female & $\begin{array}{l}\text { Rate risk } \\
\text { in males } \dagger\end{array}$ & p Valuef & Male & Female & $\begin{array}{l}\text { Rate risk } \\
\text { in malest }\end{array}$ & p Value $\neq$ & Male & Female & $\begin{array}{l}\text { Rate risk } \\
\text { in males } \dagger\end{array}$ & p Value & Male & Female & $\begin{array}{l}\text { Rate risk } \\
\text { in males }\end{array}$ & p Value $\neq$ \\
\hline $0 \cdot \cdot 15$ & 658 & 248 & $2 \cdot 7$ & 0.003 & 141 & - & - & - & 90 & 67 & $1 \cdot 3$ & 0.7 & 210 & 174 & $1 \cdot 2$ & $0 \cdot 317$ \\
\hline $16-24$ & 532 & 229 & $2 \cdot 3$ & 0.005 & 560 & 141 & $4 \cdot 0$ & 0.0002 & 437 & 67 & 6.5 & 0.0007 & 208 & 198 & $1 \cdot 1$ & 0.97 \\
\hline $25-34$ & 504 & 412 & $1 \cdot 2$ & 0.37 & 256 & 104 & $2 \cdot 5$ & 0.02 & 420 & 540 & {$[1 \cdot 3]$} & 0.6 & 129 & 137 & {$[1 \cdot 1]$} & 0.74 \\
\hline $35-54$ & 282 & 343 & {$[1 \cdot 2]$} & 0.42 & 120 & 99 & $1 \cdot 2$ & 0.68 & 180 & 288 & {$[1.6]$} & $0 \cdot 27$ & 118 & 167 & {$[1.4]$} & 0.036 \\
\hline $55-64$ & 147 & 229 & {$[1.6]$} & 0.48 & 106 & 82 & 1.3 & 0.7 & 360 & 36 & 10.0 & 0.0083 & 221 & 212 & 1.0 & 0.96 \\
\hline$\geqslant 65$ & 172 & - & - & - & 369 & 164 & $2 \cdot 3$ & 0.36 & - & - & - & - & 387 & 479 & {$[1 \cdot 2]$} & 0.55 \\
\hline All & 372 & 265 & $1 \cdot 4$ & 0.19 & 221 & 94 & $2 \cdot 3$ & 0.0001 & 237 & 130 & $1 \cdot 8$ & 0.017 & 160 & 178 & {$[1 \cdot 1]$} & $0 \cdot 23$ \\
\hline
\end{tabular}

falciparum infections, particularly in Ghana, where the rate approached $1 \%$ per visit. Malaria attack rates for travellers returning from south Asia were low; the $P$ vivax specific attack rate for this region was 167 per 100000 travellers. Rates of infection in British residents returning from the Far East or South East Asia, South America, and the Middle East were very low, with 2, 12, and 1 infection per 100000 respectively.

Reported regional attack rates by purpose of travelMalaria attack rates were usually highest in British residents travelling to malarious areas to visit friends or relatives (table II). Travellers to west Africa and south Asia constitute immigrant groups resident in Britain. The rates approached $1 \%$ in these visitors to west Africa and were higher than $1 \%$ in travellers returning from Ghana. The rates in travellers from west Africa were 6.4 times greater than the rate in those visiting friends or relatives in east Africa. Business travellers returning from east Africa, principally Kenya, were at greater risk than tourists and those visiting friends or relatives. Tourists visiting Kenya were, however, at 4-4-fold higher risk of infection compared with those visiting the Gambia.

Reported age and sex specific attack rates by region of infection-Males had a significantly higher malaria attack rate than females visiting sub-Saharan Africa (table III). Males aged between 16 and 24 returning from east Africa had a fourfold higher risk of infection compared with females of the same age, and in those returning from central or southern Africa the difference was more than sixfold higher. Boys (0-15 years) visiting west Africa had a $2 \cdot 7$-fold higher risk of infection than girls of the same age. Rates between males and females did not differ significantly in travellers to south Asia but were highest in travellers aged over 65 .

Reported rates according to duration of travel-Malaria attack rates did not always increase proportionately with the length of time abroad (table IV). The relative risk of infection in west Africa increased from 1.0 for one week to $80 \cdot 3$ when trips lasted between six months and a year. Remarkably, travellers visiting east Africa for one week were at fivefold greater risk than those abroad for one month.

\section{PROTECTION AFFORDED BY MALARIA} CHEMOPROPHYLAXIS

Types of chemoprophylactic drug taken by British travellers

No chemoprophylactic drugs were reportedly taken by $23 \%$ of travellers to west Africa, $17 \%$ of those to east Africa, $46 \%$ to central or southern Africa, and $58 \%$ to south Asia (table V). The recommended drug regimen for sub-Saharan Africa, chloroquine plus proguanil, was reportedly used by nearly half of British residents travelling to east Africa for business or on holiday and to west Africa on holiday. A fifth of holiday travellers to east Africa and to central or southern Africa used Maloprim, alone or with proguanil or chloroquine. Drugs not currently recommended (pyrimethamine, amodiaquine, and Fansidar) were used by a small proportion of all groups. 
Regional efficacy of commonly prescribed chemoprophylactic drugs

West Africa-Travellers to west Africa taking no chemoprophylaxis were at a threefold higher risk of becoming infected with $P$ falciparum than those taking chloroquine plus proguanil (table VI). The calculated efficacy of each commonly prescribed regimen was over $50 \%$, but the confidence intervals were wider with chloroquine and Maloprim. Chloroquine plus proguanil had the highest efficacy at $73 \%$ with narrow confidence intervals. Proguanil alone seemed to give greater protection than chloroquine alone.

East Africa-The $P$ falciparum attack rate in travellers taking no chemoprophylaxis in east Africa was 196

TABLE IV-Malaria attack rates (per 100000 ) and relative risk of infection in British travellers by duration of travel ${ }^{\star}$

\begin{tabular}{|c|c|c|c|c|c|c|c|c|}
\hline \multirow{2}{*}{$\begin{array}{c}\text { Duration of } \\
\text { travel } \\
\text { (weeks) }\end{array}$} & \multicolumn{4}{|c|}{ West Africa } & \multicolumn{4}{|c|}{ East Africa } \\
\hline & $\begin{array}{l}\text { No of } \\
\text { cases }\end{array}$ & $\begin{array}{l}\text { No of } \\
\text { travellers }\end{array}$ & Rate & $\begin{array}{c}\text { Relative } \\
\text { risk }\end{array}$ & $\begin{array}{l}\text { No of } \\
\text { cases }\end{array}$ & $\begin{array}{c}\text { No of } \\
\text { travellers }\end{array}$ & Rate & $\begin{array}{c}\text { Relative } \\
\text { risk } f\end{array}$ \\
\hline 1 & 9 & 14721 & 61 & $1 \cdot 0$ & 6 & 2752 & 218 & $1 \cdot 0$ \\
\hline 2 & 19 & 22387 & 85 & $1 \cdot 4$ & 8 & 11693 & 68 & {$[3 \cdot 2]$} \\
\hline 3 & 26 & 9192 & 283 & $4 \cdot 6$ & 14 & 19198 & 73 & {$[3 \cdot 0]$} \\
\hline 4 & 74 & 14472 & 511 & $8 \cdot 4$ & 6 & 14897 & 40 & {$[5 \cdot 5]$} \\
\hline $5-12$ & 68 & 12334 & 551 & $9 \cdot 0$ & 34 & 8938 & 380 & 1.7 \\
\hline $13-26$ & 13 & 347 & 3746 & $61 \cdot 4$ & 11 & 2502 & 440 & $2 \cdot 0$ \\
\hline $27-52$ & 17 & 347 & 4899 & $80 \cdot 3$ & 14 & 720 & 1944 & 8.9 \\
\hline
\end{tabular}

*Excludes cases and travellers whose stay was longer than one year.

tCompared with risk from one week's travel [] denotes reciprocal value). per 100000 . Although this was $3 \cdot 5$ times lower than for travellers taking no chemoprophylactic in west Africa, the efficacy of each drug was lower in east than west Africa (table II). The efficacy of chloroquine and chloroquine plus proguanil was $54 \%$ and that of proguanil was $36 \%$. The confidence intervals were wide for each regimen with the lower limits falling below $0 \%$. Maloprim (alone or, rarely, in combination with proguanil or chloroquine) had a very low efficacy $(9 \%)$.

\section{Compliance with chemoprophylaxis}

Poor compliance with prophylaxis compromised the protective value of all drugs (table VII). Among travellers returning from west Africa those who were non-compliant had a $2 \cdot 5$-fold higher rate of infection with $P$ falciparum than those reporting full compliance. Poorly compliant users did, however, seem to be protected still, especially with drugs taken daily rather than weekly, although the lower confidence limits for drug efficacy dropped to below $0 \%$. Everyone taking Maloprim reported full compliance. Chloroquine and chloroquine plus proguanil seemed to be as effective in east Africa as in west Africa but only in fully compliant users. The confidence intervals for drug efficacy for east Africa were, however, very wide, with lower limits below $0 \%$ for all drug regimens except chloroquine plus proguanil, and the efficacy was not significantly different. Drugs taken by non-compliant users in east

TABLE V-Proportion (\%) of British travellers reportedly using malaria chemoprophylactic drugs and purpose of travel, 1987

\begin{tabular}{|c|c|c|c|c|c|c|c|c|c|c|c|c|c|c|}
\hline \multicolumn{3}{|c|}{ West Africa } & \multicolumn{4}{|c|}{ East Africa } & \multicolumn{4}{|c|}{ Central or Southern Africa } & \multicolumn{4}{|c|}{ South Asia } \\
\hline Holiday & Business & $\begin{array}{l}\text { Visiting } \\
\text { friends } \\
\text { and } \\
\text { relations }\end{array}$ & Total & Holiday & Business & $\begin{array}{l}\text { Visiting } \\
\text { friends } \\
\text { and } \\
\text { relations }\end{array}$ & Total & Holiday & Business & $\begin{array}{l}\text { Visiting } \\
\text { friends } \\
\text { and } \\
\text { relations }\end{array}$ & Total & Holiday & Business & $\begin{array}{l}\text { Visiting } \\
\text { friends } \\
\text { and } \\
\text { relations }\end{array}$ \\
\hline
\end{tabular}

\begin{tabular}{|c|c|c|c|c|c|c|c|c|c|c|c|c|c|c|c|c|}
\hline None & 23 & 17 & 14 & 46 & 17 & 11 & 21 & 30 & 46 & 32 & 60 & 48 & 58 & 45 & 50 & 69 \\
\hline Chloroquine & 14 & 15 & 14 & 14 & 11 & 10 & 4 & 21 & 3 & 5 & 0 & 4 & 11 & 12 & 8 & 9 \\
\hline Proguanil & 15 & 10 & 21 & 16 & 8 & 10 & 4 & 6 & 7 & 5 & 13 & 4 & 8 & 12 & 7 & 5 \\
\hline Chloroquine and proguanil & 30 & 44 & 21 & 11 & 42 & 45 & 46 & 27 & 23 & 32 & 20 & 16 & 12 & 20 & 25 & 5 \\
\hline Maloprim & 4 & 2 & 11 & 0 & 16 & 20 & 13 & 9 & 14 & 21 & 7 & 12 & 6 & 7 & 7 & 5 \\
\hline Pyrimethamine & 9 & 7 & 14 & 5 & 2 & 1 & 8 & $<1$ & 3 & 5 & 0 & 4 & 4 & 3 & 2 & 5 \\
\hline Amodiaquine & 3 & 2 & 4 & 5 & 4 & 3 & 4 & 6 & 4 & 0 & 0 & 12 & $<1$ & 0 & $<1$ & 1 \\
\hline Fansidar & 2 & 2 & $<1$ & 3 & 0 & 0 & 0 & 0 & 0 & 0 & 0 & 0 & $<1$ & $<1$ & 0 & $<1$ \\
\hline
\end{tabular}

TABI.E VI - Universal efficacy ${ }^{\star}$ of chemoprophylactic drugs against P falciparum used by British travellers 1987

\begin{tabular}{|c|c|c|c|c|c|c|}
\hline & \multicolumn{3}{|c|}{ West Africa } & \multicolumn{3}{|c|}{ East Africa } \\
\hline & $\begin{array}{c}\text { Malaria } \\
\text { attack rate } \\
(\text { per } 100000)\end{array}$ & $\begin{array}{c}\text { Relative } \\
\text { risk` }\end{array}$ & $\begin{array}{c}\text { Chemoprophylactic } \\
\text { efficacy } \dagger \\
\text { (95\% confidence } \\
\text { interval) }\end{array}$ & $\begin{array}{c}\text { Malaria } \\
\text { attack rate } \\
(\text { per } 100000)\end{array}$ & $\begin{array}{c}\text { Relative } \\
\text { risk* }^{\star}\end{array}$ & $\begin{array}{c}\text { Chemoprophylactic } \\
\text { efficacy } \dagger \\
\text { (95\% confidence } \\
\text { interval) }\end{array}$ \\
\hline \multicolumn{7}{|c|}{ Unadjusted for compliance } \\
\hline Chloroquine & 275 & $2 \cdot 5$ & $60(40$ to 73$)$ & 90 & $2 \cdot 2$ & $54(-52$ to 86$)$ \\
\hline Proguanil & 219 & $3 \cdot 1$ & $68(51$ to 79$)$ & 126 & 1.6 & $36(-167$ to 85$)$ \\
\hline Chloroquine and proguanil & 183 & $3 \cdot 7$ & $73(62$ to 81$)$ & 91 & $2 \cdot 2$ & $54(-5$ to 79$)$ \\
\hline Maloprim & 266 & $2 \cdot 6$ & $61(23$ to 80$)$ & 178 & $1 \cdot 1$ & $9(-449$ to 98$)$ \\
\hline Other & 142 & & & 81 & & \\
\hline None & 681 & & & 196 & & \\
\hline \multicolumn{7}{|c|}{ Adjusted for full compliance } \\
\hline Chloroquine & 230 & $3 \cdot 0$ & $66(47$ to 79$)$ & 68 & $2 \cdot 9$ & $65(-26 t 090)$ \\
\hline Proguanil & 155 & $4 \cdot 4$ & $77(61$ to 87$)$ & 126 & 1.6 & $36(-1671085)$ \\
\hline Chloroquine and proguanil & 150 & $7 \cdot 8$ & $78(68$ to 85$)$ & 50 & $3 \cdot 9$ & $75(38$ to 89) \\
\hline Maloprim & 266 & $2 \cdot 6$ & $61(23$ to 80$)$ & 161 & $1 \cdot 2$ & $18(-2671082)$ \\
\hline
\end{tabular}

TABLE VII - Influence of compliance on efficacy of chemoprophylactic drugs against P falciparum, 1987

\begin{tabular}{|c|c|c|c|c|c|c|c|c|c|c|c|c|}
\hline & \multicolumn{6}{|c|}{ West Africa } & \multicolumn{6}{|c|}{ East Africa } \\
\hline & \multicolumn{2}{|r|}{ Compliance } & \multicolumn{2}{|c|}{ Non-compliance } & \multirow[b]{2}{*}{$\begin{array}{l}\text { Relative } \\
\text { risk }\end{array}$} & \multirow[b]{2}{*}{$\mathrm{p}$ Value } & \multicolumn{2}{|r|}{ Compliance } & \multicolumn{2}{|c|}{ Non-compliance } & \multirow[b]{2}{*}{$\begin{array}{c}\text { Relative } \\
\text { risk` }\end{array}$} & \multirow[b]{2}{*}{ p Value } \\
\hline & $\begin{array}{l}\text { Rate of } \\
\text { infection }\end{array}$ & $\begin{array}{c}\text { Chemoprophylactic } \\
\text { efficacy } \dagger\end{array}$ & $\begin{array}{l}\text { Rate of } \\
\text { infection }\end{array}$ & $\begin{array}{c}\text { Chemoprophylactic } \\
\text { efficacy } \dagger\end{array}$ & & & $\begin{array}{l}\text { Rate of } \\
\text { infection }\end{array}$ & $\begin{array}{c}\text { Chemoprophylactic } \\
\text { efficacy }\end{array}$ & $\begin{array}{c}\text { Rate of } \\
\text { infection }\end{array}$ & $\begin{array}{c}\text { Chemoprophylactic } \\
\text { efficacy } \dagger\end{array}$ & & \\
\hline Chloroquine & 230 & 66 & 571 & 16 & $2 \cdot 5$ & 0.023 & 68 & 65 & 272 & $<1$ & $4 \cdot 0$ & 0.081 \\
\hline Proguanil & 155 & 77 & 372 & 45 & $2 \cdot 4$ & $0 \cdot 026$ & 126 & 36 & - & & & \\
\hline $\begin{array}{l}\text { Chloroquine and } \\
\text { proguanil }\end{array}$ & 150 & 78 & 370 & 46 & $2 \cdot 5$ & 0.0067 & 50 & 75 & 245 & $<1$ & $5 \cdot 0$ & $<0.0001$ \\
\hline Maloprim & 266 & 61 & - & & & & 161 & 18 & 282 & $<1$ & $1 \cdot 8$ & 0.317 \\
\hline
\end{tabular}

- Inadequate data for analyses.

*Compliance $v$ non-compliance.

†Percentage reduction in risk of infection attributed to chemoprophylaxis. 
Africa did not seem to offer any protection against $P$ falciparum infection.

\section{Discussion}

We have described a method for collecting and measuring the national risk of malaria in British residents returning from malarious areas. Although multiple analyses were not possible, the data indicated significant differences in risk between the various groups of travellers. Former crude analyses of data suggested that immigrant groups and young males were at greatest risk, ${ }^{5}$ and our present data support such findings. Rates of infection with $P$ falciparum in travellers returning from west Africa were particularly high and were double those of 1986. A further rise in incidence has since been reported, in 1988.: Transmission in Ghana was especially high. In contrast, rates of infection from south Asia have dropped in recent years and seem to mirror a lull in transmission from this region, but this is thought to be temporary as a sharp rise in $P$ vivax malaria has been reported during 1989. High infection rates in immigrant groups from west Africa cannot be blamed solely on the absence of chemoprophylaxis: though prophylaxis has been shown to reduce attack rates by a half, the rates of infection in immigrants taking chemoprophylaxis still remained in the order of $0.7 \%$. Infection rates in travellers to east Africa were not as high as expected; business travellers seemed to be at greatest risk, and this group contributed towards the disproportionately high attack rate in British residents abroad for only one week. Rates in longer term travellers, including those visiting relatives or friends, were lower, possibly because many of these travellers were based in Nairobi.

Incidence data alone have previously implied that males, particularly children and young adults, were at greater risk than females." This was assumed to be partly because more males than females visited high risk malarious areas. Our data suggest that males do seem to have a higher risk of infection than females visiting the same regions. This may relate to an increased exposure to infection or decreased protection, or both. An equal proportion of males and females, however, reported taking chemoprophylaxis, and the duration of stay abroad did not differ significantly between males and females. ${ }^{1+}$ Further analyses on compliance with prophylaxis indicated that males were less compliant than females in each age category and that younger travellers were less compliant than older travellers, which has been reported previously. We thus conclude that an important reason for the excess risk in males is because of their decreased compliance with prophylaxis.

The efficacy of commonly prescribed chemoprophylactic drugs was calculated on a regional basis. Resistance of $P$ falciparum to chloroquine and alternative antimalarial drugs varies geographically, even by microlocation. Such precision was not possible using routine surveillance data, which were not adequate to measure efficacy for individual countries. However, as recommendations for chemoprophylaxis are generally made regionally, and year by year the proportion of travellers visiting each country within a region varies only marginally, ${ }^{12}$ efficacy within regions was considered to be of some value. Firstly, the mean values, when read together with their confidence intervals, illustrated that drugs had a higher protective value in west Africa than in east Africa. Secondly, the data indicated that monoprophylaxis offered less protection, particularly for proguanil alone and for Maloprim in travellers to east Africa. Chloroquine plus proguanil is thus the preferred regimen for Africa. Thirdly, and of great importance, the data measured the decreased value of prophylaxis if drugs were not taken on a regular basis. The protective effect of drugs was particularly low in poorly compliant travellers to east Africa.

The incidence of $P$ falciparum infections has increased since this study were performed; it is thought that the protective value of chloroquine plus proguanil has fallen. New drugs to which strains of $P$ falciparum are sensitive have been developed and will shortly be available in Britain. Past experience of toxicity associated with newer, more potent drugs, however, illustrates the need for caution in prescribing drugs too widely. ${ }^{3+}$ One drug, mefloquine, has been recommended for prophylaxis against multiresistant strains of $P$ falciparum malaria. ${ }^{15}$ Its use will be restricted to travellers abroad for short periods because it has a particularly long half life, and longer term use may cause problems with the dosing schedule. Our data illustrate, however, that it is long term rather than short term travellers who will be most in need of a new drug.

We thank the staff from the international passenger survey and the Malaria Reference Laboratory for their participation. PAPH was supported by the Leverhulme Trust and the Malaria Action Programme of the World Health Organisation. We thank Shell International for their contribution towards fees for the International Passenger Survey of the Office of Population Censuses and Surveys.

I World Health Organisation. The epidemiology of drug resistant malaria parasites: memorandum from a WHO meeting. Bull WHO 1987;65:797816.

2 Bradley DJ. Current trends in malaria in Britain. I R Soc Med 1989;82 (Suppl $17): 8-14$

3 Peto TEA, Gilks CF. Strategies for the prevention of malaria in travellers: comparison of drug regimens by means of risk benefit analysis. Lancel 1986;i:1256-60.

+ Phillips-Howard PA, West L. Serious adverse drug reactions to pyrimethamine-sulphadoxine, pyrimethamine-dapsone, and to amodiaquine in mine-sulphadoxine, pyrimeth

5 Phillips-Howard PA, Bradley DJ, Blaze M, Hurn M. Malaria in Britain: 1977-1986. Br.Med f 1988:296:245-8.

6 McLarty DG, Webher R, Jaatinen M, et al. Chemoprophylaxis of malaria in non-immune residents in Dar es Salaam, Tanzania. Lancet 1984;ii:656-9.

7 Lobel HO, Phillips-Howard PA, Brandling-Bennett AD, et al. Malaria incidence and prevention among European and North American travellers to Kenya. Bull WHO (in press)

8 Fogh S, Schapira A, Bygbjerg IC, et al. Malaria chemoprophylaxis in travellers to cast Africa: a comparative prospective study of chlorequine plus proguanil with chlorequine plus sulfadoxine-pyrimethamine. $\mathrm{Br}$ Med 7 1988:296:820-2.

9 Harrics AD, Foreshaw CJ. Friend HM. Malaria prophslaxis amongst British residents of Lilungwe and Kasungu districts, Malawi. Trans $R$ Soc Trop Med Hyg 1988:82:690-2

10 Phillips-Howard PA. Efficacy of drug prophylaxis. F R Soc Med 1989:82 Suppl $17: 18-30$.

11 Phillips-Howard PA, Mitchell J, Bradlev D). Validation of malaria surveillance reports: implications for studies of malaria risk. F Fpidemel cellance reports: implication

12 Phillips-Howard PA, Breeze E, Lakin C, Bradley D). Short term travel to malarious areas; malaria risk in UK travellers. Travel Medicine International malarious area

13 Kirkwood B. Essentials of medical statistics. Oxford: Blackwell Scientific Publications, 1988: 174-5.

It Phillips-Howard PA. The epidemiology of malaria in Britain (PhD) thesis]. London: University of London, $1988.366 \mathrm{pm}$

15 Prophelaxis against malaria for travellers from the United Kingdom. Br Med 7 1989:299:1087-9.

Accepled 15 December 1989 , 